\title{
Natural and Cellular Immune Responses in Flinders Sensitive and Resistant Line Rats
}

\author{
Elliot M. Friedman, Ph.D., Michael R. Irwin, M.D., and David H. Overstreet, Ph.D.
}

Major depression is associated with impairments in natural and cellular immune responses. This study characterized baseline natural and cellular immune function in the Flinders Sensitioe Line (FSL) genetic animal model of depression and in Flinders Resistant Line (FRL) controls. Splenic natural cytotoxicity per natural killer (NK) cell was significantly lower in the FSL rats, suggesting that NK cells are less actirated at rest in the FSL rats than in the FRL controls. Neither lymphocyte proliferative responses nor interleukin-2 production differed between the two strains. Resting baseline concentrations of plasma

KEY WORDS: Flinders Sensitioe Line; Depression; Natural killer; Lymphocyte proliferation; Interleukin-2

Major depression has been associated with abnormalities of immune function (Herbert and Cohen 1993a), including a reduction of natural killer (NK) cell cytotoxicity (Irwin and Gillin 1987; Urich et al. 1988; Nerozzi et al. 1989) and lymphocyte proliferation responses (Kronfol et al. 1983; Schleifer et al. 1984; Kronfol and House 1985). The mechanisms underlying these immunological abnormalities remain unclear, although altered regulation of immune function by the brain, neuroendocrine, and endocrine systems have been hypothesized

From the Department of Psichiatry, Lniversity of California, San Diego, and San Diego Veterans Affairs Medical Center, San Diego, California (EMF, MRI); and Skipper Bowles Center for Alcohol Studies and Department of Psychiatry (DHO), University of North Carolina at Chapel Hill, Chapel Hill.

Address correspondence to: Flliot Friedman, Ph.D., Psychiatry Department (151), Veterans Affairs Medical Center, 3350 La Jolla Village Drive, San Diego, CA 92161.

Received August 7, 1995; revised October 3,1995 ; accepted October 13,1995 adrenocorticotropic hormone and corticosterone were similar between the FSL and FRL rats, indicating that hypothalamo-pituitary adrenal axis activation did not mediate inmunological differences. FSL rats show abnormalities in natural immunity similar to those found in clinically depressed human beings, indicating that this animal model may be useful in understanding the neural and neuroendocrine mechanisms associated with immune alterations in depression. [Neuropsychopharmacology 15:314-322, 1996]

to play a role (Kronfol and House 1985; Irwin et al. 1991; Darko et al. 1992; Irwin and Friedman 1995). Further elucidation of the physiological mechanisms that mediate depression-related immune dysfunction will almost certainly have to rely on animal models.

A number of different types of animal models of depression have been developed, including behavioral models (e.g., learned helplessness) and genetic models (e.g., rats bred for social inhibition or hyperactivity) (Maier 1984; Willner 1991; Overstreet 1992). Studies examining immune function in these animal models have shown that inescapable footshock that induces learned helplessness in rats suppresses NK cytotoxicity, lymphocyte proliferation, and antibody responses (Laudenslager et al. 1983; Laudenslager et al. 1988; Maier and Laudenslager 1988; Sacerdote et al. 1994). Furthermore, in mice selectively bred for social inhibition, Petitto et al. $(1994,1993)$ demonstrated that NK and lymphocyte responses are impaired, indicating a potential relationship between genetically determined behavioral traits and abnormal immune function. The aim of the present study was to extend the previous research by examin- 
ing immunological responses in another genetic animal model of depression, the Flinders Sensitive Line (FSL) rat.

The FSL rats, and their control counterpart Flinders Resistant Line (FRL) rats, were originally established by selectively breeding Sprague-Dawley rats for high (FSL) and low (FRL) sensitivity to the anticholinesterase agent diisopropyl fluorophosphate (DFP) (Overstreet et al. 1979). Subsequent evaluations of the FSL rats revealed that, in addition to their cholinergic hypersensitivity, they expressed behavioral and physiological abnormalities similar to those found in clinical depression. For example, compared to FRL controls the FSL rats exhibit lower locomotor activity, impaired active avoidance responses, increased immobility in stressful swim tests, increased rapid eye movement (REM) sleep, and deficits in cognitive function (Overstreet 1993). In his recent review, Overstreet (1993) established that the FSL model successfully meets the criteria of face, construct, and predictive validity for an animal model of clinical depression. Immunological studies involving the FSL animals and FRL controls have demonstrated greater reductions in serum complement in the FSL rats after a mild stress paradigm (Ayensu et al. 1995) and increased susceptibility to anaphylactic shock (Djuric et al. 1995).

We hypothesized that the FSL animals would exhibit depressionlike reductions in NK cytotoxic responses, NK activity per cell, NK cell numbers, lymphocyte proliferation responses, and interleukin-2 (IL-2) production compared to the FRL rats. We chose to conduct the immunological evaluations under resting conditions in order to conform to the studies involving depressed human subjects and to determine whether differences in immune responses between the two strains would be evident in the absence of stress or pharmacological challenge.

\section{MATERIALS AND METHODS}

\section{Animals}

The subjects for this study were male $(n=20)$ and FRL $(n=23)$ rats bred at the University of North Carolina, Chapel Hill. Following shipment, all rats were housed in pairs in the Animal Research Facility at the San Diego Veterans Affairs Medical Center and given at least 2 weeks to adjust to the new environment. The average age of the rats was 3 months; body weights differed depending on the strain (see Results). The housing environment was maintained at $22^{\circ} \mathrm{C}$ with lights on at 0600 and off at 1800 . Food and water were available ad libitum. To reduce exposure to odors, noises, or infectious agents, rats were kept in enclosed laminar flow racks. Specialized microisolator filters were inserted into cage lids during transport of the animals for handling and experiments. All rats were handled for 1 week before experimental procedures to reduce the stress associated with human contact. The experimenters remained blind to the strain of each animal until the conclusion of all immunological procedures.

\section{Cell Preparation}

Rats were rapidly decapitated and truncal blood collected in EGTA-treated $50-\mathrm{ml}$ tubes on ice. Spleens were removed to sterile culture plates containing phosphatebuffered saline (PBS) and teased apart with sterile needles. Splenocytes were aspirated, underlayered by Ficoll-Hypaque (Sigma Chemical Col, St. Louis, MO), and spun for 30 minutes at 1,200 RPM. The mononuclear cell (MNC) fraction was removed, washed twice, tested for viability by trypan blue exclusion, and resuspended at a final density of $10^{7}$ cells $/ \mathrm{ml}$ in complete medium: 1:1 RPMI 1640:Dulbeccos Modified Eagles Medium (Mediatech, Washington, D.C.) supplemented with $10 \%$ Fetal Clone serum (Hyclone Laboratories Inc, Logan, UT), $25 \mathrm{mM}$ Hepes (Irvine Scientific, Santa Ana, CA), $5 \times 10^{-5}$ M 2-mercaptoethanol (Gibco, Grand Island, NY), $4 \mathrm{mM}$ glutamine (Core Research Facility, La Jolla, CA), and 50 $\mu \mathrm{g} / \mathrm{ml}$ gentamicin (Sigma).

\section{NK Cytotoxicity Assay}

To determine strain-related differences in natural immunity NK activity was measured in a standard 3-hour chromium-release assay. Splenic MNC effector cells were cultured in triplicate with the YAC-1 mouse lymphoma target cells [American Type Culture Collection (ATCC), Rockville, MD] at effector-to-target ratios of 100:1, 50:1, 25:1, and 12.5:1 in U-bottom microtiter plates. YAC cells were incubated for 1 hour at $37^{\circ} \mathrm{C}$ with 100 $\mu \mathrm{Ci}$ sodium chromate (New England Nuclear, Boston, $\mathrm{MA}$ ), washed twice with complete medium, and resuspended at $10^{5}$ cells $/ \mathrm{ml}$. $100 \mu \mathrm{l}$ MNC were incubated with $100 \mu \mathrm{l}$ YAC cells in $200-\mu \mathrm{l}$ wells. Spontaneous and maximal chromium release was determined by culturing $100 \mu \mathrm{l}$ YAC cell suspension with $100 \mu \mathrm{l}$ complete medium or $100 \mu \mathrm{l} 1 \mathrm{M}$ hydrochloric acid, respectively. Mircotiter plates were spun at 300 RPM for 2 minutes and incubated for 3 hours at $37^{\circ} \mathrm{C}$. The supernatants were removed from each well and aspirated into borosilicate tubes, and chromium release was determined in a gamma counter. Percent specific cytotoxicity was calculated using the following formula: (release from sample - spontaneous release)/(maximal release - spontaneous release). Data are expressed as percent specific cytotoxicity. The cytotoxicity data were also converted to lytic units to permit a quantitative evaluation of relative cytotoxicity (Trinchieri 1989). One lytic unit was defined as the number of effector cells killing $20 \%$ of the target cells, calculated using the equation $y=A(1-$ $e^{-K x}$ ) (Pross and Maroun 1984). The data are expressed as lytic units per $10^{6}$ cells. 
Table 1. Mean ( ( SEM) Body Weights, Neuroendocrine Measures, and Splenic MNC Numbers in FSL and FRL Rats

\begin{tabular}{|c|c|c|c|c|}
\hline Variable & FSL & FRL & $t$-Value & $p$-Value \\
\hline Body weight (g) & $\begin{array}{l}396.25 \\
(12.56)\end{array}$ & $\begin{array}{l}468.13 \\
(14.74)\end{array}$ & 3.19 & 0.01 \\
\hline $\mathrm{ACTH}(\mathrm{pg} / \mathrm{ml})$ & $\begin{array}{c}50.22 \\
(10.42)\end{array}$ & $\begin{array}{c}56.87 \\
(21.45)\end{array}$ & 0.28 & 0.78 \\
\hline Corticosterone $(\mu \mathrm{g} / \mathrm{dl})$ & $\begin{array}{l}16.93 \\
(3.61)\end{array}$ & $\begin{array}{l}18.13 \\
(2.89)\end{array}$ & 0.26 & 0.80 \\
\hline Splenic MNC & $3.98 \times 10^{7}$ & $3.27 \times 10^{7}$ & 1.04 & 0.16 \\
\hline
\end{tabular}

\section{NK Cell Numbers}

MNC $\left(5 \times 10^{5}\right)$ were incubated with $5 \mu l$ mouse anti-rat NK monoclonal antibody (NKR-Pl fluorescein-labeled monoclonal, Harlan Bioproducts for Science, Inc., Madison, WI) for 30 minutes on ice in complete darkness. This antibody is specific for rat NK and lymphokine-activated killer cells, and double labeling flow cytometric experiments have shown that it successfully distinguishes these cells from B cells $(0.6 \% \mathrm{OX} 6+/ \mathrm{NKR}-\mathrm{Pl}+)$, cytotoxic $\mathrm{T}$ cells $(8.2 \% \mathrm{OX} 8+/ \mathrm{NKR}-\mathrm{PI}+)$, T cells $(0.5 \%$ $\mathrm{OX} 19+/ \mathrm{NKR}-\mathrm{Pl}+)$, and macrophages $(0.3 \% \mathrm{OX} 41+/$ $\mathrm{NKR}-\mathrm{Pl}+$ ) (Chambers et al. 1989). Cells were washed, fixed using a $1 \%$, formaldehyde solution, and enumerated by a fluorescence-activated cell sorter (FACSTAR; Becton-Dickinson, Rutherford, NJ). Data are expressed as the number of $\mathrm{NK}+$ cells per $10^{6}$ lymphocytes.

\section{Lymphocyte Proliferation}

To assess $\mathrm{T}$ and $\mathrm{B}$ lymphocyte proliferative responses, MNC $\left(10^{5}\right)$ were cultured in triplicate at $37^{\circ} \mathrm{C}$ for 72 hours with $100 \mu \mathrm{l}$ complete medium (unstimulated), concanavalin A (Con A, $10 \mu \mathrm{g} / \mathrm{ml}$; Sigma), Staphylococcal enterotoxin $B$ (SEB, $2.5 \mu \mathrm{g} / \mathrm{ml}$; Sigma), or pokeweed mitogen (PWM, $10 \mu \mathrm{g} / \mathrm{ml}$; Sigma). Con A and SEB both require the presence of monocytes for optimal stimulation of $\mathrm{T}$ cell proliferation, although their mechanisms of action differ (Salamon et al. 1992). In order to evaluate monocyte-independent $\mathrm{T}$ cell responses, an anti-Tcell receptor antibody (G4.18 mouse anti-rat-CD3, 2.5 $\mu \mathrm{g} / \mathrm{ml}$; PharMingen, San Diego, CA) was also used to induce proliferation; the anti-CD3 antibody was adhered to flat-bottom microtiter plates before the addition of MNC. After a 72-hour incubation, cultures were pulsed (4 hours) with $1 \mu \mathrm{Ci}\left[{ }^{3} \mathrm{H}\right]$ thymidine and harvested. Thymidine incorporation was determined in a beta counter (Packard, Meriden, CT). Data are expressed as net counts per minute (CPM): stimulated CPM - unstimulated CPM.

\section{Interleukin-2 Release}

Stimulated IL-2 production was measured by culturing MNC $\left(10^{5}\right)$ with Con A and SEB (same concentrations used for proliferative assays) at $37^{\circ} \mathrm{C}$ for 72 hours. Cul-

Table 2. Mean (- SEM) Lymphocyte Proliferation Responses and IL-2 Production in FSL and FRL Rats

\begin{tabular}{|c|c|c|c|c|}
\hline Mitogen & FSL & FRL & $t$-Value & $p$-Value \\
\hline \multicolumn{5}{|l|}{ Lymphocyte proliferation } \\
\hline $\operatorname{Con} A(10 \mu g / m l)$ & $\begin{array}{l}14,320) \\
(2,360)\end{array}$ & $\begin{array}{l}12,201 \\
(1,646)\end{array}$ & 0.02 & 0.79 \\
\hline $\operatorname{SEB}(2.5 \mu \mathrm{g} / \mathrm{ml})$ & $\begin{array}{l}18,744 \\
(2,640)\end{array}$ & $\begin{array}{l}1+, 312 \\
(2,757)\end{array}$ & 1.04 & 0.30 \\
\hline Anti-CD3 $(5 \mu \mathrm{g} / \mathrm{ml})$ & $\begin{array}{l}31,384 \\
(4,983)\end{array}$ & $\begin{array}{l}31,381 \\
(5,406)\end{array}$ & 0.00 & 1.0 \\
\hline PWM $(10 \mathrm{mg} / \mathrm{ml})$ & $\begin{array}{l}27,968 \\
(2,390)\end{array}$ & $\begin{array}{l}24,625 \\
(2,545)\end{array}$ & 0.79 & 0.44 \\
\hline \multicolumn{5}{|l|}{ Interleukin-2 production } \\
\hline Con $A(10 \mu g / m l)$ & $\begin{array}{l}13.45 \\
(4.19)\end{array}$ & $\begin{array}{l}12.15 \\
(2.20)\end{array}$ & 0.07 & 0.79 \\
\hline $\mathrm{SEB}(2.5 \mathrm{mg} / \mathrm{ml})$ & $\begin{array}{c}+.00 \\
(0.77)\end{array}$ & $\begin{array}{c}4.18 \\
(0.52)\end{array}$ & 0.04 & 0.85 \\
\hline
\end{tabular}



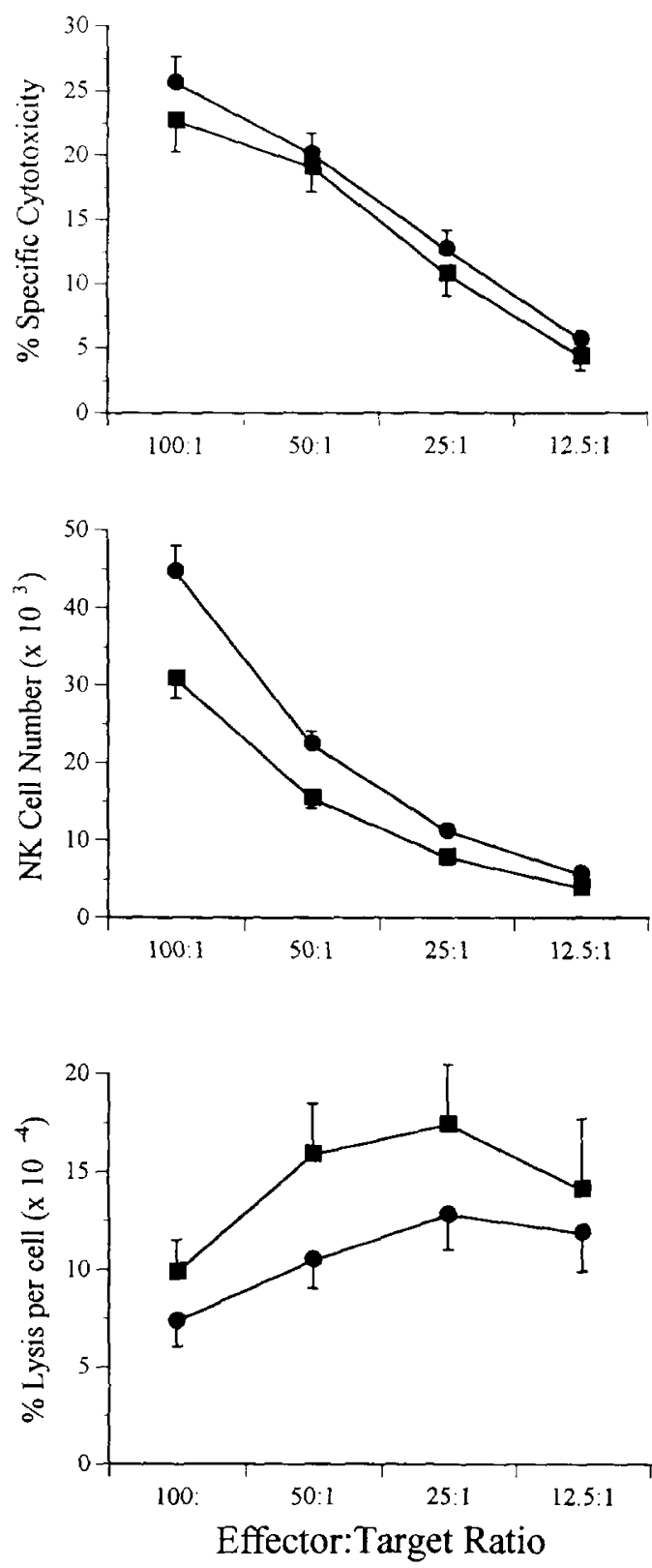

Figure 1. Top, mean ( \pm SEM) splenic NK specific cytotoxicity in FSL (solit circle, $n=20$ ) and FRL rats (solid square, $n=23$ ). There was a significant main effect for effector-to-target (E:T) ratio $[F(3,108)=62.10, p<.001]$, but no difference between the two strains $[F(1,36)=0.98, \beta=.33]$ or a ratio-by-strain interaction $[F(3,108)=0.23 p=.87]$. Mittlle, mean ( \pm SEM) number of splenic NK cells. Cell numbers at the 100:1 were significantly higher in the FSL rats than in FRL controls $[t(41)=11.67, \mu<$ .01]. Cell numbers for the remaining E:T ratios were derived from these numbers and are depicted for illustrative purposes. Bottom, mean (= SEM) percent NK specific cytotoxicity per cell. Percent specific cytotoxicity values for individual animals were divided by individual NK cell numbers at each E:T ratio and averaged to generate mean percent specific cytotoxicity per cell at the four E:T ratios. Cytotoxicity per cell was significantly lower in the FSL rats than in the FRL controls $[F(1,41)=10.47$, $p<.01]$. There was also a significant effect of E:T ratio $(F(3,123)=5.91, p<.01]$, but no ratio-by-strain interaction $[F(3,123)=0.34, p=.80]$. ture supernatants were then harvested and frozen at $-20^{\circ} \mathrm{C}$. Samples were later thawed and incubated overnight at $37^{\circ} \mathrm{C}$ with IL-2-dependent CTLL-2 murine T cells (ATCC). Cultures were pulsed ( 4 hours) with $1 \mu \mathrm{Ci}$ $\left[{ }^{3} \mathrm{H}\right]$ thymidine and harvested, and thymidine incorporation was determined in a beta counter.

\section{Neuroendocrines}

Plasma concentration of adrenocorticotropic hormone (ACTH) and corticosone (B) from truncal blood samples were determined using commercially available radioimmunoassay kits (ACTH: Nichols Institute Diagnostics, San Juan Capistrano, CA; B: ICN Biomedicals, Inc., Costa Mesa, CA).

\section{Statistical Analyses}

Data were generally analyzed by two-tailed independent $t$ tests. Differences in NK specific cytotoxicity were determined by two-factor analysis of variance (ANOVA): factor 1 was strain and factor 2 was the effector-to-target ratio. For technical and experimental reasons, data sets were not complete for all variables. For this reason, sample sizes are noted for all variables.

\section{RESULTS}

As previously reported (Overstreet 1993), the FSL rats in the current study weighed significantly less than their FRL counterparts (Table 1). Plasma levels of ACTH and corticosterone were within the range of typical baseline values, and no differences in neuroendocrines between the FSL and FRL rats were observed (Table 2).

\section{NK Cytotoxicity}

Similar numbers of spleen MNC were recovered from the FSL $\left(3.27 \times 10^{7}\right.$ cells $)$ and FRL $\left(3.98 \times 10^{7}\right.$ cells $)$ rats (Table 1), despite the marked difference in body weight between the two strains. NK cytotoxicity data are depicted in Figure 1. NK specific cytotoxicity did not differ between the FSL and FRL strains at any of the four effector-target ratios $(p=.33)$. Conversion of the cytotoxicity data to lytic units produced the same pattern of results (Figure 2). Enumerating NK cells revealed a significantly greater percentage of NK cells in the spleens of FSL rats than that for FRL controls $(p<.001)$. To evaluate resting NK cell activation, we calculated NK cytotoxicity on a per-cell basis. This calculation revealed that NK killing per cell was significantly lower in the FSL rats than in the FRL controls $(p<.01$; Figure 1 ). Lytic units per cell were also significantly lower in the FSL rats $(p<.01$; Figure 2$)$. 

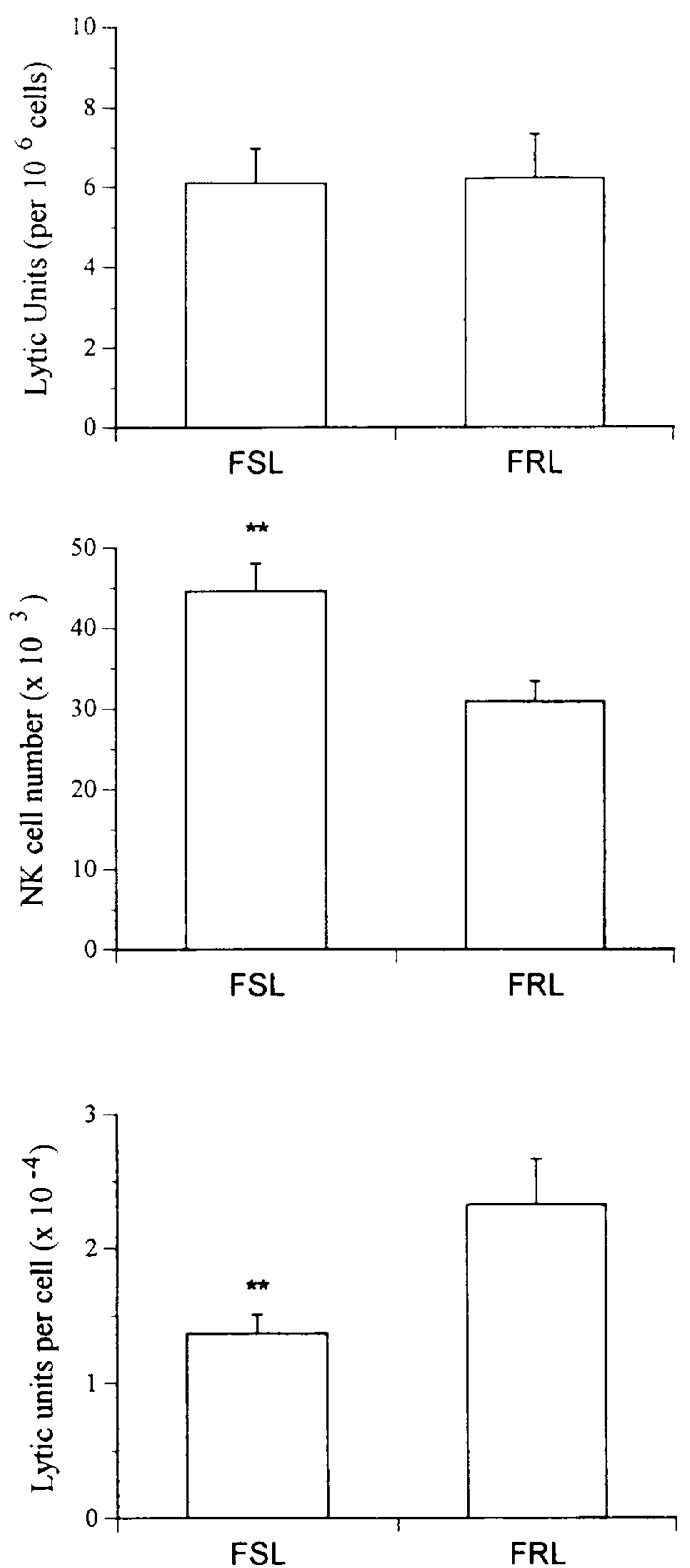

Figure 2. Top, mean (= SEM) lytic units per $10^{\circ}$ cells in FSL and FRL rats. There was no difference in lytic activity between the two strains $[t(41)=0.07, p=.47]$. Middle, mean ( \pm SEM) number of splenic NK cells in FSL and FRL rats. The cell number was significantly higher in the FSL rats than in FRL controls $[t(41)=10.98, p<.01]$. Bottom, mean $( \pm$ SEM) lytic activity per cell in FSL and FRL rats. Lytic unit values for individual animals were divided by individual NK cell numbers to generate lytic units per cell. Lytic units per cell was significantly lower in the FSL rats than in the FRL controls $[t(41)=6.17, p<.01]$.

\section{Lymphocyte Proliferation}

Lymphocytes responses to Con A, SEB, PWM, and antiCD3 stimulation did not differ between the FSL and FRL strains (Table 2). IL-2 production in response to stimulation with Con A and SEB did not differ between the FSL and FRL rats (Table 2).

\section{DISCUSSION}

In the present study, the FSL rats were hypothesized to show alterations in NK activity, cell number, lymphocyte proliferation responses, and cytokine production at baseline like those observed in depressed individuals (Kronfol et al. 1983; Schleifer et al. 1984; Kronfol and House 1985; Irwin and Gillin 1987; Nerozzi et al. 1989; Maes et al. 1991). The results provided partial support for this hypothesis. Activation of NK cells at rest, as determined by NK lytic activity per cell, was significantly lower in the FSL rats than in the FRL controls. However, lymphocyte proliferative responses and cytokine production did not differ between the two strains.

NK cells are essential components of host defense against viral and bacterial infection and neoplasia (Ritz 1989; Trinchieri 1989; Whiteside and Herberman 1989), and cell activation is a necessary prerequisite for host defense (Trinchieri 1989). NK cells can become activated through exposure to virally infected or neoplastic cells, through incubation with cytokines, such as IL-2 or interferon (IFN), or through a combination of the two (Trinchieri 1989). In the present study, NK lytic activity per cell was significantly lower in the FSL rats, indicating decreased activation of resting NK cells in these rats. These results parallel clinical findings examining NK activity and cells numbers in clinical depression. Although NK activity is typically lower in depressed subjects than in controls (Irwin and Gillin 1987; Levy et al. 1991; Evans et al. 1992; Maes et al. 1994b); decreases in the number of circulating NK cells are not consistently reported (Darko et al. 1989; Maes et al. 1994a). Moreover, in the studies in which both NK activity and NK cell numbers have been evaluated simultaneously, reduced NK activity is not consistently correlated with changes in NK cell number (Irwin and Gillin 1987; Irwin et al. 1987; Evans et al. 1992; Maes et al. 1994b). Collectively, these results suggest that diminished killing capacity of individual NK cells may be one mechanism whereby NK activity is reduced in subjects who are clinically depressed. It is not known whether this diminished activation of splenic NK cells in the FSL rats reflects increased vulnerability to illnesses requiring optimal NK function, as disease incidence in the Flinders animals has not been evaluated.

The mechanisms by which NK cells are less activated in the FSL rats are unclear. There was no apparent defect in T cell production of IL-2, a potent stimulator of NK activity (Trinchieri 1989), but it is possible that the sensitivity of NK cells to cytokine stimulation is impaired in the FSL rat. Interferon (IFN) also exerts a stimulatory influence on NK cytotoxicity in vivo and in vitro, and NK cells themselves are important sources of IFN (Trinchieri 1989). We did not examine IFN release in vitro. Finally, it is possible that NK cells in the FSL rats are under tonic inhibition by factors extrinsic to the 
immune system. The neuroendocrine system, for example, has been implicated in the modulation of immune function (Besedovsky et al. 1975; Munck et al. 1984), although in the present study no differences in circulating levels of ACTH or corticosterone were found. The sympathetic nervous system, through the release of norepinephrine and neuropeptide $Y$, is known to exert an inhibitory influence on NK activity (Irwin et al. 1990, 1991; Madden et al. 1993; Nair et al. 1993), although resting sympathetic tone in the Flinders strains has not been systematically evaluated.

Given the FSL rats are selected on the basis of cholinergic hypersensitivity, it is also conceivable that cholinergic systems may contribute to abnormal NK activity in these animals. The parasympathetic nervous system has been argued to play a role in the modulation of immune responses through cholinergic mechanisms (Rinner et al. 1995), and cholinergic hypersensitivity is hypothesized to underlie greater susceptibility to anaphylactic shock in the FSL rats (Djuric et al. 1995). The evidence for modulation of NK activity by cholinergic systems, however, is mixed. In one study, administration of the muscarinic agonist arecoline peripherally and into the brain enhanced lytic activity in pre-activated NK cells (Demissie et al. 1995), but a second study using an anticholinesterase inhibitor demonstrated suppression of IL-2-enhanced NK activity in vitro (Casale et al. 1992). Thus, the contribution of endocrine and neuroendocrine systems to altered NK activity in the FSL rats remains to be determined.

The numbers of NK cells in the FSL spleens were selectively increased, in contrast with clinical studies of depressed patients in which no changes or small decreases in NK cell numbers are found. Importantly, the splenic compartment was examined in the present study, whereas clinical studies of depressives have enumerated circulating numbers of NK cells. Circulating NK cell numbers have not yet been determined in the FSL rats, and therefore it is not known whether the reduction in NK cell number in these animals reflects a compartmental shift or a decrement in the total number of NK cells.

In vitro lymphocyte proliferation and IL-2 production have been used to assess $T$ cell function in clinical and preclinical studies. Suppression of lymphocyte proliferation and IL-2 release have been associated with stress in human beings (Glaser et al. 1990; Herbert and Cohen 1993b), nonhuman primates (Coe 1993), and rats (Keller et al. 1983; Maier and Laudenslager 1988) and with clinical depression (Herbert and Cohen 1993a). Lymphocyte proliferation responses have also been reported to be lower in socially inhibited rats than in aggressive ones (Petitto et al. 1994). Using the nonspecific mitogen $\mathrm{Con} \mathrm{A}$, which does not require processing and presentation by monocytes (Rosenstreich and Mizel 1978), and the superantigen SEB, which stimulates the proliferation of $\mathrm{T}$ cells through interaction with class II major histocompatability regions on accessory cells and induces cytokine release from monocytes (Salamon et al. 1992), we found that both Con A and SEB induced significant $T$ cell proliferative responses and IL-2 production. However, there were no differences between FSL and FRL strains. Furthermore, using the G4.18 mouse anti-rat-CD3 clone, previously shown to activate rat $\mathrm{T}$ cells in vitro (Nicolls et al. 1993), we found that responses to $T$ cell receptor binding were also similar in the FSL and FRL rats. It is important to note, however, that $T$ cell numbers and subsets were not determined in the present study. It is possible that $\mathrm{T}$ cell numbers, like NK cells, may have differed between the two strains, and that differential proliferative capacity and/or $\mathrm{cy}$ tokine production may have been obscured by differences in cell number.

An alternative possibility is that lymphocyte proliferation responses are not lower in the FSL rats at rest, and that this dissociation of NK and lymphocyte responses may accurately reflect immunological abnormalities in clinical depression. For example, some clinical studies have failed to demonstrate depression-related reductions in lymphocyte proliferative responses (see Herbert and Cohen 1993a; Irwin 1995, for reviews). Moreover, a recent review of the literature of depression and immunity using stringent methodological criteria found that reductions in lymphocyte proliferation were associated with clinical depression in only one out of five studies (Irwin 1995). In contrast, seven out of eight studies meeting these methodological criteria reported depression-related decrements in NK activity. Finally, psychophysiological substrates of negative affect in nondepressed women are associated with decrements in NK activity, but not lymphocyte proliferation responses (Kang et al. 1991). Thus, the influence of psychological variables on these two indices of immune function may be dissociable in some circumstances, and NK function appears to be the more sensitive to psychological influence.

Although some aspects of the present results appear to conflict with clinical studies of depression-related abnormalities in NK specific cytotoxicity or lymphocyte proliferation, these findings do not preclude the possibility that the FSL rat may represent a valuable model for examining the mechanisms of immune alterations relevant to depression. For example, it is possible that immunological differences between the FSL and FRL rats may emerge only after some form of challenge; serum complement levels were similar between the two strains at baseline, but significantly lower in the FSL rats after chronic mild stress (Ayensu et al. 1995). Moreover, other behavioral and physiological differences between FSL and FRL rats, such as locomotor inhibition (Overstreet 1986) and plasma corticosterone levels (Overstreet et al. 1986; Ayensu et al. 1995), only become evi- 
dent after stress or pharmacological challenge. It should also be noted that reductions in NK activity in clinically depressed human beings are completely abolished after clinical treatment (Irwin et al. 1992), indicating that abnormal immune responses in clinical depression may be more closely related to the "state" of acute depression than to the "trait" of susceptibility to depression. This possibility is further supported by research showing that immune responses are significantly negatively correlated with increasing severity of depressive symptoms (Schleifer et al. 1989). For these reasons, further research examining the possible differential effects of stress on natural and cellular immune responses in FSL and FRL rats is warranted.

In summary, the current study extends previous research involving FSL rats by demonstrating abnormalities in NK function in these animals. As the FSL rat is the result of selective breeding for a specific physiological trait, hypersensitivity to cholinergic agonism, it would appear to be a uniquely valuable tool for the examination of immune regulation by the central and peripheral nervous systems. These results also extend previous immunological research with animal models of depression and offer tentative support for the possibility that the FSL may be a valuable model for determining the relationship between depression and immunological dysfunction.

\section{ACKNOWLEDGMENTS}

This research was supported by NIMH Grants MH10881 (EF) and MH $4+275$ (MI) and by a VA Merit Review (MI).

\section{REFERENCES}

Ayensu WK, Pucilowski O, Mason GA, Overstreet DH, Rezvani AH, Janowsky DS (1995): Effects of chronic mild stress on serum complement activity, saccharin preference and corticosterone levels in Flinders lines of rats. Physiol Behav 57:165-169

Besedorsky H, Sorkin E, Keller M, Muller J (1975): Changes in blood hormone levels during the immune response. Proc Soc Exp Biol Med 150:466-470

Casale GP, Bavari S, Gold RE, Vitzthum EF (1992): Inhibition of interleukin-2-stimulated enhancement of human natural killer (NK) cell activity by carbaryl, an anticholinesterase insecticide. Toxicol Let 63:299-311

Chambers WH, Vujanovic NL, DeLeo AB, Olszowy MW, Herberman RB, Hiserodt JC (1989): Monoclonal antibody to a triggering structure expressed on rat killer cells and adherent lymphokine-activated killer cells. J Exp Med 169:1373-1389

Coe CL (1993): Psychosocial factors and immunity in nonhuman primates: A review. Psvchosom Med 55:298-308
Darko DF, Gillin JC, Risch SC, Bulloch K, Golshan S, Tasevska Z, Hamburger RN (1989): Immune cells and the hypothalamic-pituitary axis in major depression. Psychiatry Res 25:173-179

Darko DF, Irwin MR, Risch SC, Gillin JC (1992): Plasma betaendorphin and natural killer cell activity in patients with major depression. Psychiatry Res 43:111-119

Demissie S, Rogers CF, Hiramoto NS, Ghanta VK, Hiramoto RN (1995): Arecoline a muscarinic cholinergic agonist conditions central pathways that modulate natural killer cell activity. J Neuroimmunol 59:57-63

Djuric VJ, Overstreet DH, Bienenstock J, Perdue MH (1995): Immediate hypersensitivity in the Flinders rat: Further evidence for a possible link between susceptibility to allergies and depression. Brain Behav Immun 9:196-206

Evans DL, Folds JD, Petitto JM, Golden RN, Pedersen CA, Corrigan M, Gilmore JH, Silva SG, Quade D, Ozer H (1992): Circulating natural killer cell phenotypes in men and women with major depression. Relation to cytotoxic activity and severity of depression. Arch Gen Psychiatry 49:388-395

Glaser R, Kennedy S, Lafuse WP, Bonneau RH, Speicher C, Hillhouse J, Kiecolt-Glaser JK (1990): Psychological stress-induced modulation of interelukin-2 receptor gene expression and interleukin-2 production in peripheral blood leukocytes. Arch Gen Psychiatry 47:707-712

Herbert TB, Cohen S (1993a): Depression and immunity: A meta-analytic review. Psychol Bull 113:472-486

Herbert TB, Cohen S (1993b): Stress and immunity in humans: A meta-analytic review. Psychosom Med 55:364379

Irwin MR (1995): Psychoneuroimmunology of depression. In Bloom FE, Kupfer DJ (eds), Psychopharmacology: The Fourth Generation of Progress. New York, Raven, pp 983-998

Irwin MR, Gillin JC (1987): Impaired natural killer cell activity among depressed patients. Psychiatry Res 20:181182

Irwin MR, Smith TL, Gillin JC (1987): Reduced natural killer cytotoxicity in depressed patients. Life Sci 41:2127-2133

Irwin MR, Hauger RL, Jones L, Provencio M, Britton KT (1990): Sympathetic nervous system mediates central corticotropin-releasing factor induced suppression of natural killer cytotoxicity. J Pharmacol Exp Ther 255(1): $101-107$

Irwin MR, Brown M, Patterson T, Hauger R, Mascovich A, Grant I (1991): Neuropeptide $Y$ and natural killer cell activity: Findings in depression and Alzheimer caregiver stress. FASEB ] 5:3100-3107

Irwin M, Lacher U, Caldwell C (1992): Depression and reduced natural killer cell cytotoxicity: A longitudinal study of depressed patients and control subjects. Psychol Med 22:1045-1050

Irwin MR, Friedman EM (in press): Developmental aspects of psychoneuroimmunology. In Lewis M (ed), Child and Adolescent Psychiatry: A Textbook, ed. 2. Baltimore, William \& Wilkins

Kang D, Davidson RJ, Coe CL, Wheeler RE, Tomarken AJ (1991): Frontal brain asymmetry and immune function. Behav Neurosci 105:860-869 
Keller SE, Weiss JM, Schleifer S], Miller NE, Stein M (1983): Stress-induced suppression of immunity in adrenalectomized rats. Science 221:1301-1304

Kronfol Z, House JD (1985): Depression, hypothalamic-pituitary adrenocortical activity and lymphocyte function. Psychopharmacol Bull 21:476-478

Kronfol Z, Silva J, Greden J, Dembinski S, Gardner R, Carroll B (1983): Impaired lymphocvte function in depressive illness. Life Sci 33:241-247

Laudenslager ML, Ryan SM, Drugan RC, Hyson RL, Maier SF (1983): Coping and immunosuppression: Inescapable but not escapable shock suppresses lymphocyte proliferation. Science 221:568-570

Laudenslager ML, Fleshner M, Hofstadter P, Held PE, Simons L, Maier SF (1988): Suppression of specific antibody production by inescapable shock: Stability under varying conditions. Brain Behar Immun 2:92-101

Levy EM, Borrelli DJ, Mirin SM, Salt P, Knapp PH, Peirce C, Fox BH, Black PH (1991): Biological measures and cellular immunological function in depressed psychiatric inpatients. Psychiatry Res 36:157-167

Madden KS, Ackerman KD, Liv'nat S, Felten S, Felten DL (1993): Neonatal sympathetic denervation alter the development of natural killer (NK) cell activity in F344 rats. Brain Behar Immun 7:344-351

Maes M, Bosmans E, Suy E, Vandervorst $C$, delonckheere $C$, Raus J (1991): Depression-related disturbances in mitogen-induced lymphocyte responses and interleukin-1 $\beta$ and soluble interleukin-2 receptor production. Acta Psychiatr Scand 84:379--386

Maes M, Lambrechts 1, Suy E, Vandervorst C, Bosmans E (1994a): Absolute number and percentage of circulating natural killer, non-MHC-restricted $\mathrm{T}$ cytotoxic, and phagocytic cells in unipolar depression. Neuropsychobiol 29:157-163

Maes M, Meltzer HY, Stevens W, Calabrese J, Cosyns I' (1994b): Natural killer cell activity in major depression: Relation to circulating natural killer cells, cellular indices of the immune response, and depressive phenomenology. Prog Neuropsychopharmacol Biol Psychiatry $18: 717-730$

Maier SF (1984): Learned helplessness and animal models of depression. Prog Neuropsychopharmacol Biol Psychiatry 8:435-446

Maier SF, Laudenslager ML (1988): Inescapable shock, shock controllability, and mitogen stimulated lymphocyte proliferation. Brain Behay Immun 2:87-91

Munck A, Guyre PM, Holbrook NJ (1984): Physiological functions of glucocorticoids in stress and their relation to pharmacologic actions. Endocr Rec 5:25-44

Nair MPN, Schwartz SA, Wu K, Kronfol Z (1993): Effect of neuropeptide $Y$ on natural killer activity of normal human lymphocytes. Brain Behav Immun 7:70-78

Nerozzi D, Santoni A, Bersani G, Magnani A, Bressan A, Pasini A, Antonozzi I, Frajese G (1989): Reduced natural killer cell activity in major depression: Neuroendocrine implications. Psychoneuroendocrinology 14:295-301

Nicolls MR, Aversa GG, Pearce NW, Spinelli A, Berger MF, Gurley KE, Hall BM (1993): lnduction of long-term spe- cific tolerance to allografts in rats by therapy with an anti-CD3-like monoclonal antibody. Transplantation 55: $459-468$

Overstreet DH (1986): Selective breeding for increased cholinergic function: Development of a new animal model of depression. Biol Psychiatry 21:49-58

Overstreet DH (1992): Genetic animal models of endogenous depression. In Driscoll P (ed), Genetically-Defined Animal Models of Neurobehavioral Dysfunction. Boston, Birkhauser, pp 81-114

Overstreet DH (1993): The Flinders Sensitive Line rats: A genetic animal model of depression. Neurosci Biobehav Rev 17:51-68

Overstreet DH, Russell RW, Helps SC, Messenger M (1979): Selective breeding for sensitivity to the anticholinesterase, DFP. Psychopharmacology 65:15-20

Overstreet DH, Booth R, Dana R, Risch SC, Janowsky DS (1986): Enhanced elevation of corticoserone following arecoline administration to rats selectively bred for increased cholinergic function. Psychopharmacology 88: $129-130$

Petitto JM, Lysle DT, Gariepy J, Clubb PH, Cairns RB, Lewis MH (1993): Genetic differences in social behavior: Relation to natural killer cell function and susceptibility to tumor development. Neuropsychopharmacol 8:35-43

Petitto JM, Lysle DT, Gariepy J, Lewis MH (19940: Association of genetic differences in social behavior and cellular immune responsiveness: Effects of social experience. Brain Behav Immun 8:111-122

Pross HF, Maroun JA (1984): The standardization of NK cell assays for use in studies of biological response modifiers. J Immunol Methods 68:235-249

Rinner I, Felsner P, Falus A, Skreiner E, Kukulansky T, Globerson A, Hirokawa K, Schauenstein K (1995): Cholinergic signals to and from the immune system. Immunol Lett 44:217-220

Ritz J (1989): The role of natural killer cells in immune surveillance. N Engl J Med 320:1748-1749

Rosenstreich DL, Mizel SB (1978): The participation of macrophages and macrophage cell lines in the activation of T lymphocytes by mitogens. Immunol Rev 40:102-135

Sacerdote P, Manfredi B, Bianchi M, Panerai AE (1994): Inter mittent but not continuous inescapable footshock stress affects immune responses and immunocyte beta-endorphin concentrations in the rat. Brain Behav Immun 8:251260

Salamon FT, Fayen JD, Leonard ML, Finegan CK, Rich EA (1992): Accessory function of human mononuclear phagocytes for lymphocyte responses to the superantigen Staphylococcal Enterotoxin B. Cell Immunol 141: $466-484$

Schleifer SI, Keller SE, Meyerson AT, Raskin MI, Davis KL, Stein $M$ (1984): Lymphocyte function in major depressive disorder. Arch Gen Psychiatry 41:484-486

Schleifer SJ, Keller SE, Bond RN, Cohen J, Stein M (1989): Major depressive disorder and immunity: Role of age, sex, severity, and hospitalization. Arch Gen Psychiatry $46: 81-87$ 
Trinchieri G (1989): Biology of natural killer cells. Adv Immunol 47:187-376

Lrich A, Muller CH, Aschauer H, Resch F, Zielinski CC (1988): Lytic effector cell function in schizophrenia and depression. J Neuroimmunol 18:291-301
Whiteside TL, Herberman RB (1989): The role of natural killer cells in human disease. Clin Immunol Immunopathol 53:1-23

Willner P (1991): Animal models as simulations of depression. Trends Neurosci 12:131-136 